J Arid Land (2013) 5(1): 60-70

doi: $10.1007 / \mathrm{s} 40333-013-0142-6$

jal.xjegi.com; www.springer.com/40333

\title{
Soil water and salt distribution under furrow irrigation of saline water with plastic mulch on ridge
}

\author{
LiJuan $\mathrm{CHEN}^{*}$, Qi FENG \\ Alxa Desert Ecohydrological Experimental Research Station, Cold and Arid Regions Environmental and Engineering Research \\ Institute, Chinese Academy of Sciences, Lanzhou 730000, China
}

\begin{abstract}
Furrow irrigation when combined with plastic mulch on ridge is one of the current uppermost water-saving irrigation technologies for arid regions. The present paper studies the dynamics of soil water-salt transportation and its spatial distribution characteristics under irrigation with saline water in a maize field experiment. The mathematical relationships for soil salinity, irrigation amount and water salinity are also established to evaluate the contribution of the irrigation amount and the salinity of saline water to soil salt accumulation. The result showed that irrigation with water of high salinity could effectively increase soil water content, but the increment is limited comparing with the influence from irrigation amount. The soil water content in furrows was higher than that in ridges at the same soil layers, with increments of $12.87 \%$ and $13.70 \%$ for MMF9 (the treatment with the highest water salinity and the largest amount of irrigation water) and MMF1 (the treatment with the lowest water salinity and the least amount of irrigation water) on 27 June, respectively. The increment for MMF9 was gradually reduced while that for MMF1 increased along with growth stages, the values for 17 August being $2.40 \%$ and $19.92 \%$, respectively. Soil water content in the ridge for MMF9 reduced gradually from the surface layer to deeper layers while the surface soil water content for MMF1 was smaller than the contents below $20 \mathrm{~cm}$ at the early growing stage. Soil salinities for the treatments with the same amount of irrigation water but different water salinity increased with the water salinity. When water salinity was $6.04 \mathrm{dS} / \mathrm{m}$, the less water resulted in more salt accumulation in topsoil and less in deep layers. When water salinity was $2.89 \mathrm{dS} / \mathrm{m}$, however, the less water resulted in less salt accumulation in topsoil and salinity remained basically stable in deep layers. The salt accumulation in the ridge surface was much smaller than that in the furrow bottom under this technology, which was quite different from traditional furrow irrigation. The soil salinities for MMF7, MMF8 and MMF9 in the ridge surface were $0.191,0.355$ and $0.427 \mathrm{dS} / \mathrm{m}$, respectively, whereas those in the furrow bottom were $0.316,0.521$ and $0.631 \mathrm{dS} / \mathrm{m}$, respectively. The result of correlation analysis indicated that compared with irrigation amount, the irrigation water salinity was still the main factor influencing soil salinity in furrow irrigation with plastic mulch on ridge.
\end{abstract}

Keywords: water and salt transportation; furrow irrigation; saline water; soil salinity; soil water content

Citation: LiJuan CHEN, Qi FENG. 2013. Soil water and salt distribution under furrow irrigation of saline water with plastic mulch on ridge. Journal of Arid Land, 5(1): 60-70.

About $90 \%$ of irrigated areas in the world are under surface irrigation, mainly furrow irrigation (Tiercelin and Vidal, 2006), which is low energy and investment consuming. In arid and semi-arid regions of China, furrow irrigation is adopted on almost all major thinly planted crops (corn, cotton, sunflower, etc.). Furrow irrigation in combination with plastic mulch is a highly efficient water-saving irrigation technology. While the plastic film covers the ridge, it allows the plants to grow through holes and a certain gap is maintained in the furrow for irrigation. Because of its notable functions for saving water, increasing yield, reducing soil evaporation and preserving soil temperature, furrow irrigation with plastic mulch on ridge

*Corresponding author: LiJuan CHEN (E-mail: chenlj2001@126.com)

Received 2012-03-06; revised 2012-05-28; accepted 2012-08-14

(C) Xinjiang Institute of Ecology and Geography, Chinese Academy of Sciences, Science Press and Springer-Verlag Berlin Heidelberg 2013 
is remarkably improved water use efficiency. Nowadays, furrow irrigation with plastic mulch on ridge has become one of the major measures for water-saving in most arid regions of northwest China.

At present, the use of saline water has become an important measure to relieve agricultural water shortage all over the world (Mantell et al., 1985; Oster, 1994). Saline water with total dissolved solids (TDS) of $2-5 \mathrm{~g} / \mathrm{L}$ is widely distributed in the northwestern seaboard regions of China (Ministry of Agriculture, 2000), and has a large potential for exploitation and use. Nevertheless, large-scale use of saline water may lead to serious soil salinization. The harmful effects of soil salinization would last a long time and the reparation would be difficult or impossible once salinization problems occur (Rhoades et al., 1999; Rengasamy, 2002). Therefore, feasible and scientific methods of irrigation with saline water are particularly important.

For furrow irrigation with saline water, relevant studies about its effects on soil characteristics and crop yield have been conducted in arid regions in several countries (Forrest et al., 1985; Zohrab et al., 1985; Evans et al., 1990; Moreno et al., 1995). However, systematic studies in China are relatively few. As plastic film would remarkably affect the dynamics of water and salt in soil, soil water-salt movement and its spatial distribution characteristics would be largely changed under furrow irrigation with plastic mulch on ridge. Therefore, studies on water and soil movement in soil under furrow irrigation of saline water with plastic mulch on ridge would be an un-neglected important issue.

In this research, an experiment was designed and conducted in the field to: (1) study the dynamics of water and salt movement and their spatial distribution characteristics in soil during furrow irrigation with plastic mulch on ridge under different irrigation water quantity and quality; and (2) establish mathematical relationships for soil salinity, irrigation amount and water salinity so as to evaluate the contribution of irrigation amount and water salinity to soil salt accumulation.

\section{Materials and methods}

\subsection{Study area}

The field experiment was conducted at Test and De- monstration Base for Agricultural Water-saving and Ecological Construction $\left(103^{\circ} 12^{\prime} 03.4^{\prime \prime} \mathrm{E}, 38^{\circ} 42^{\prime} 40.2^{\prime \prime} \mathrm{N}\right)$, Minqin of Gansu, China, from 28 April to 30 September, 2010. The location is at the boundary of Minqin oasis and Tengger Desert, with a typical continental desert climate (Fig. 1). It is characterized by scarce precipitation (about $110 \mathrm{~mm}$ annually), strong evaporation (more than 2,664 mm), frequent winds (the number of days with strong winds of more than 17 $\mathrm{m} / \mathrm{s}$ exceeds 25 ), abundant sand sources and long sunshine hours $(3,028 \mathrm{~h})$. The annual average temperature is $7.8^{\circ} \mathrm{C}$, and the lowest winter temperature can fall to $-27.3^{\circ} \mathrm{C}$ whereas summer maxima can rise to $41.1^{\circ} \mathrm{C}$. The annual average humidity is $45 \%$ and the maximum soil frozen depth is $115 \mathrm{~cm}$. The underground water table of the experimental field is deeper than 18 $\mathrm{m}$. The soil of the field is sandy loam and its physicochemical properties are presented in Table 1.

\subsection{Experimental design and treatments}

Maize (Yuyu No.22) was cultivated using irrigation water of three salinity levels $(2.89,4.46$ and 6.04 $\mathrm{dS} / \mathrm{m})$ and three irrigation quotas $(2,400,3,000$ and $3,600 \mathrm{~m}^{3} / \mathrm{hm}^{2}$ ). A bifactorial experiment in a Randomized Completely Block Design was adopted. A total of nine treatments were used, with three replicates for each (Table 2). Irrigation water of different salinity levels for the experiment was obtained by mixing the water from two wells in the required proportion. One well was located in the experimental station (fresh water (FW), with a salinity level of 1.09 $\mathrm{dS} / \mathrm{m})$ and the other was in Huanghui village $\left(103^{\circ} 36^{\prime} 11.9^{\prime \prime} \mathrm{E}, 39^{\circ} 02^{\prime} 56.4^{\prime \prime} \mathrm{N}\right)$ in the Minqin county (saline water (SW), with the salinity level of 15.92 $\mathrm{dS} / \mathrm{m})$. The ion concentrations of the groundwater were presented in Table 3 and the scheme of water allocation was calculated as follows:

$$
M=\frac{M_{f} \times Q_{f}+M_{s} \times Q_{s}}{Q_{f}+Q_{s}} .
$$

Where $M$ is the salinity level of irrigation water after mixing, $\mathrm{g} / \mathrm{L} ; M_{f}$ is the salinity level of water from FW, $\mathrm{g} / \mathrm{L} ; M_{s}$ is the salinity level of water from SW, g/L; $Q_{f}$ is the amount of water from $\mathrm{FW}, \mathrm{m}^{3} / \mathrm{hm}^{2}$; and $Q_{s}$ is the amount of water from $\mathrm{SW}, \mathrm{m}^{3} / \mathrm{hm}^{2}$. 


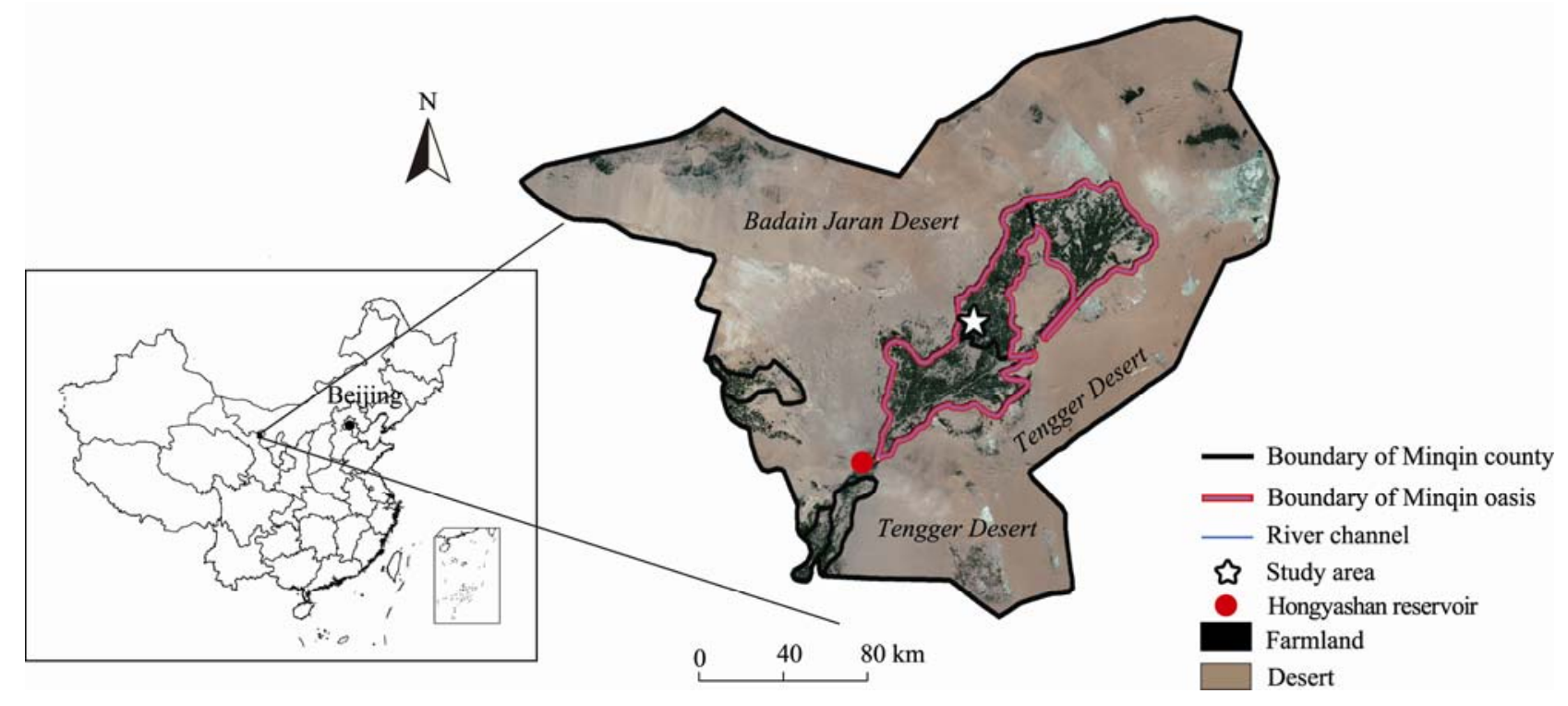

Fig. 1 Location of the study area

Table 1 Physical and chemical properties of experimental soil

\begin{tabular}{|c|c|c|c|c|c|c|c|c|c|c|}
\hline $\begin{array}{l}\text { Soil layer } \\
(\mathrm{cm})\end{array}$ & $\begin{array}{l}\text { Texture } \\
\text { class }\end{array}$ & $\begin{array}{l}\text { Organic } \\
\text { matter } \\
(\%)\end{array}$ & $\begin{array}{c}\text { Total } \\
\text { nitrogen } \\
(\%)\end{array}$ & $\begin{array}{c}\text { Total } \\
\text { phosphorus } \\
(\%)\end{array}$ & $\begin{array}{c}\text { Total } \\
\text { potassium } \\
(\%)\end{array}$ & $\begin{array}{c}\text { Available } \\
\text { nitrogen } \\
(\mathrm{mg} / \mathrm{kg})\end{array}$ & $\begin{array}{l}\text { Available } \\
\text { phosphorus } \\
(\mathrm{mg} / \mathrm{kg})\end{array}$ & $\begin{array}{l}\text { Available } \\
\text { potassium } \\
(\mathrm{mg} / \mathrm{kg})\end{array}$ & $\begin{array}{l}\text { Soil salinity } \\
\quad(\mathrm{dS} / \mathrm{m})\end{array}$ & $\mathrm{pH}$ \\
\hline $0-20$ & Sandy loam & 0.70 & 0.058 & 0.12 & 1.75 & 28.90 & 19.02 & 140 & 0.192 & 8.92 \\
\hline $20-40$ & Sandy loam & 0.73 & 0.056 & 0.11 & 1.75 & 26.10 & 4.01 & 140 & 0.230 & 7.45 \\
\hline $40-60$ & Sandy loam & 0.51 & 0.058 & 0.12 & 1.75 & 17.50 & 1.72 & 140 & 0.302 & 8.05 \\
\hline $60-80$ & Clay & 0.24 & 0.025 & 0.09 & 1.50 & 10.20 & 3.67 & 70 & 0.297 & 7.97 \\
\hline $80-100$ & Clay & 0.23 & 0.024 & 0.11 & 1.50 & 11.10 & 3.32 & 90 & 0.330 & 7.79 \\
\hline $100-120$ & Sand & 0.33 & 0.037 & 0.09 & 1.50 & 11.90 & 5.04 & 100 & 0.375 & 7.60 \\
\hline
\end{tabular}

Table 2 Irrigation schedule at different crop growth stages

\begin{tabular}{|c|c|c|c|c|c|c|c|c|}
\hline \multirow[b]{2}{*}{ Treatment } & \multicolumn{2}{|c|}{ Surface water } & \multicolumn{5}{|c|}{ Saline groundwater } & \multirow[b]{2}{*}{$\begin{array}{l}\text { Irrigation } \\
\text { quota } \\
\left(\mathrm{m}^{3} / \mathrm{hm}^{2}\right)\end{array}$} \\
\hline & $\begin{array}{c}\text { Water } \\
\text { salinity } \\
(\mathrm{dS} / \mathrm{m}) \\
\end{array}$ & $\begin{array}{c}\text { Irrigation amount } \\
\text { on } 8 \mathrm{June} \\
\left(\mathrm{m}^{3} / \mathrm{hm}^{2}\right)\end{array}$ & $\begin{array}{l}\text { Water } \\
\text { salinity } \\
(\mathrm{dS} / \mathrm{m})\end{array}$ & $\begin{array}{c}\text { Irrigation } \\
\text { amount on } 24 \\
\text { June }\left(\mathrm{m}^{3} / \mathrm{hm}^{2}\right)\end{array}$ & $\begin{array}{c}\text { Irrigation } \\
\text { amount on } 12 \\
\text { July }\left(\mathrm{m}^{3} / \mathrm{hm}^{2}\right) \\
\end{array}$ & $\begin{array}{c}\text { Irrigation amount } \\
\text { on 26July } \\
\left(\mathrm{m}^{3} / \mathrm{hm}^{2}\right)\end{array}$ & $\begin{array}{c}\text { Irrigation amount } \\
\text { on } 14 \text { August } \\
\left(\mathrm{m}^{3} / \mathrm{hm}^{2}\right)\end{array}$ & \\
\hline MMF1 & 0.52 & 450 & 2.89 & 450 & 450 & 600 & 450 & 2,400 \\
\hline MMF2 & 0.52 & 450 & 4.46 & 450 & 450 & 600 & 450 & 2,400 \\
\hline MMF3 & 0.52 & 450 & 6.04 & 450 & 450 & 600 & 450 & 2,400 \\
\hline MMF4 & 0.52 & 450 & 2.89 & 600 & 600 & 750 & 600 & 3,000 \\
\hline MMF5 & 0.52 & 450 & 4.46 & 600 & 600 & 750 & 600 & 3,000 \\
\hline MMF6 & 0.52 & 450 & 6.04 & 600 & 600 & 750 & 600 & 3,000 \\
\hline MMF7 & 0.52 & 450 & 2.89 & 750 & 750 & 900 & 750 & 3,600 \\
\hline MMF8 & 0.52 & 450 & 4.46 & 750 & 750 & 900 & 750 & 3,600 \\
\hline MMF9 & 0.52 & 450 & 6.04 & 750 & 750 & 900 & 750 & 3,600 \\
\hline
\end{tabular}

Table 3 Chemical composition of source water used in the experiment

\begin{tabular}{crrrrrrrrr}
\hline Water source & $\mathrm{HCO}_{3}{ }^{-}$ & $\mathrm{Cl}^{-}$ & $\mathrm{SO}_{4}{ }^{2-}$ & $\mathrm{Ca}^{2+}$ & $\mathrm{Mg}^{2+}$ & $\mathrm{Na}^{+}$ & $\mathrm{K}^{+}$ & $\mathrm{TDS}$ & $\mathrm{EC}(\mathrm{dS} / \mathrm{m})$ \\
\hline $\mathrm{FW}$ & 267 & 93 & 307 & 97 & 40 & 109 & 7.0 & 921 & 1.09 \\
$\mathrm{SW}$ & 689 & 2,906 & 6,334 & 438 & 1,043 & 2,655 & 33.6 & 14,099 & 15.92 \\
Surface water & 150 & 29 & 126 & 41 & 13 & 64 & 2.0 & 425 & 0.52 \\
\hline
\end{tabular}


There were three large tanks for the irrigation system. The first and second tanks were filled with water from FW and SW respectively, and the third was used for mixing water. The irrigation water was supplied by pumps and the amount was controlled by a water meter. According to local production experiences, the first irrigation for all treatments used surface water which was supplied from Hongyashan reservoir by channels and the fourth irrigation water amount was slightly increased over others to meet crop growing requirement.

\subsection{Agronomic practices}

After the experimental field was plotted (18 plots and each plot was $12 \mathrm{~m}$ long and $3 \mathrm{~m}$ wide, Fig. 2), ridged (each ridge was $60 \mathrm{~cm}$ wide and $30 \mathrm{~cm}$ high, each furrow was $40 \mathrm{~cm}$ wide) and mulched with plastic film of $120 \mathrm{~cm}$ wide (10-cm gap was maintained between two pieces of plastic film, which were jointed in the midline of furrows to allow water to infiltrate), two rows of maize were planted on each ridge (the plant density was approximately 45,000 plants $/ \mathrm{hm}^{2}$ ). The date of application and amount of fertilizer used, spraying of pesticides and other agricultural measures followed the recommendations from the Bureau of Agriculture, Minqin county (Yang et al., 2003)

\subsection{Observation and analysis}

The information of precipitation was obtained from the standard meteorological observation station of the base. Soil samples were obtained in a group of ridges and furrows from each plot with an auger before the maize was sowed and before and after each irrigation and effective precipitation during the whole growth period. The depth of sampling ranged from 0 to 100 $\mathrm{cm}$ (at 20-cm intervals) in furrows and 0 to $120 \mathrm{~cm}$ in ridges. All soil samples were divided into two parts. One part was used for measuring soil water contents by gravimetric method and another part was used for preparing soil solutions. Samples used for the preparation of soil solutions were air-dried and sieved through a 1-mm mesh. Soluble salt estimates were based on extracts of 1:5 soil/water ratio $\left(\mathrm{EC}_{1: 5}\right)$, which was determined using a conductivity meter. All data were analyzed using PASW Statistics 18.0 and Surfer 8.0.

\section{Results and discussion}

\subsection{Precipitation}

The total rainfall during the entire maize growth period was $84.4 \mathrm{~mm}$ in 2010 (Fig. 3). There were 5 rainy days ( $\geq 5 \mathrm{~mm}$ per day), which contributed $37.86 \mathrm{~mm}$. The distribution of rainfall was confined mainly to the early and terminal growth stages.

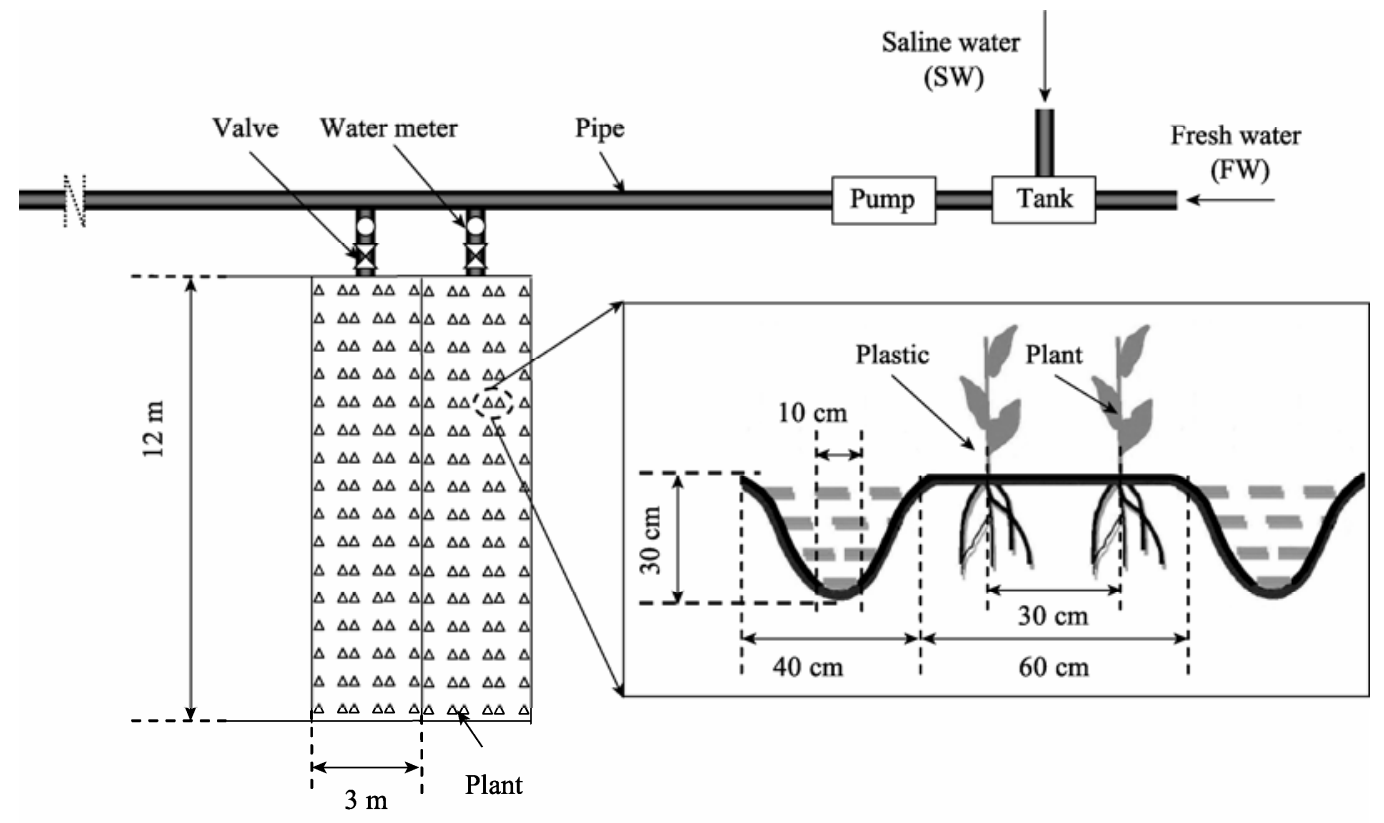

Fig. 2 Layout of the furrow irrigation of saline water with plastic mulch on ridge 


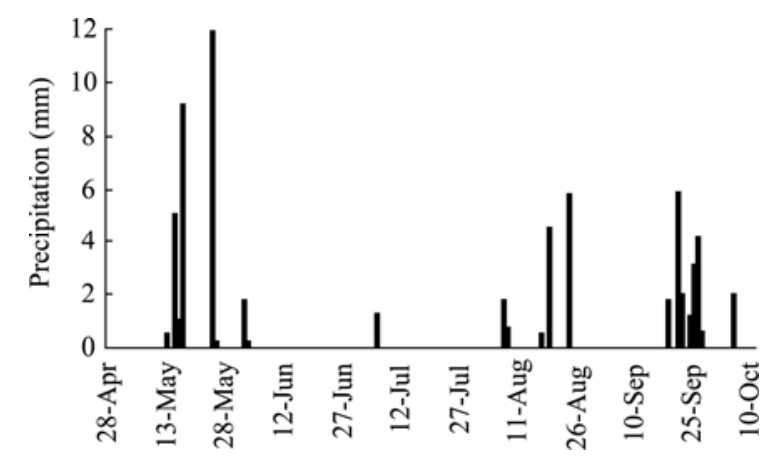

Fig. 3 Precipitation during the growth period of maize in 2010

\subsection{Variations of soil water content during the entire growth period}

The variations of soil water content in furrows for different treatments before and after irrigation seasons were shown in Fig. 4. Compared with each treatment, the differences of soil water content evoked by irrigation amount were larger than the differences evoked by water salinity during the early growth stages of the maize plants. On the $60^{\text {th }}$ day after sowing, no significant differences were observed for the treatments with the same irrigation amount at different water salinity. For example, the average soil water contents at the depth from 0 to $100 \mathrm{~cm}$ for MMF7, MMF8 and MMF9 were $15.63 \%$,
$15.80 \%$ and $16.07 \%$, respectively. However, the differences for the treatments with the same water salinity but different irrigation amount were significant. For example, the average soil water contents from 0 to $100 \mathrm{~cm}$ for MMF1, MMF4 and MMF7 were $12.54 \%, 14.17 \%$ and $15.63 \%$, respectively (with the SD of 2.13, 2.58 and 2.24, respectively). The influences of water salinity on soil water content gradually increased along with the advance of growth period.

On the $111^{\text {th }}$ day after sowing, remarkable differences were observed for the treatments with the same irrigation amount but different water salinity. The average soil water contents for MMF7, MMF8 and MMF9 were $15.22 \%, 15.97 \%$ and $16.62 \%$, respectively. Soil water content increased with irrigation water salinity. This result indicated that excessive irrigation with water of high salinity could affect the structural characteristics of soil to a great extent. These results are similar to those previously reported by Guo et al. (2005) and Feng et al. (2011). Ben-Asher et al. (2006) explained that the higher soil water content in saline treatments resulted from the relatively low water consumption of vines under medium and high salinity. Jiang et al. (2010) found that severe salt stress markedly inhibited the water uptake and that

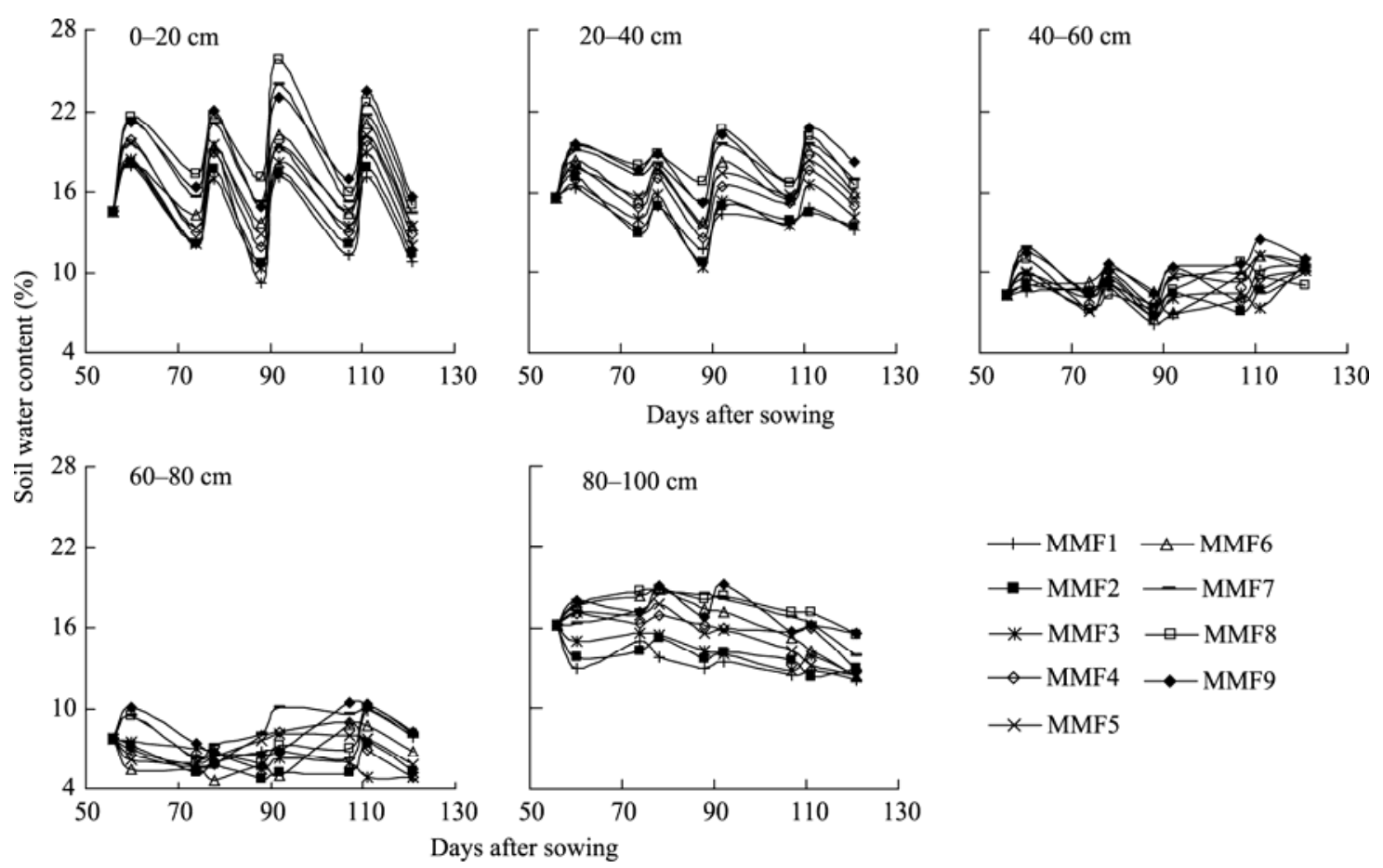

Fig. 4 The temporal dynamics of soil water content for different treatments during the entire growth period of maize 
more water was left in the soil. We speculate that the exchange and adsorption happens between the salt ions brought by the saline water and the soil colloid and the native ions of the soil during irrigation periods. The increasing sodium content enlarges the hydration degree of the soil particles, which easily results in the separation of those particles. Along with the water movement, the particles move down and deposit and then block the flow of water, decrease the actual discharge area of the water flow, form compacted weak water layer and reduce soil permeability. Ultimately, the deep percolation is reduced and the soil water content increases relatively. However, the effect of water salinity on soil water content is limited comprehensively.

On the $111^{\text {th }}$ day after sowing, the average soil water content from 0 to $100 \mathrm{~cm}$ for MMF3 (with the maximum salinity level and minimum irrigation amount) was $12.30 \%$. This value was $23.74 \%$ lower than that for MMF7 (15.22\%, with the minimum salinity level and maximum irrigation amount). Therefore, the irrigation amount is still the major decisive factor which affects the soil water content when using saline water.

\subsection{Spatial distribution characteristics of soil water content}

The spatial distribution diagrams (taking the central position of furrows as the symmetry axis) of soil water contents for MMF9 and MMF1 on 27 June and 17 August (at the end of the $2^{\text {nd }}$ and $5^{\text {th }}$ irrigations) were shown in Fig. 5. From the soil depth of 30 to $90 \mathrm{~cm}$ in Fig. 5, the soil water contents in furrows for MMF9 and MMF1 were higher than those in ridges at the same soil layers on 27 June. The average soil water contents for the two treatments were $15.71 \%$ and $12.19 \%$ in furrows, and $13.91 \%$ and $10.72 \%$ in ridges, respectively (the increments being $12.87 \%$ and $13.70 \%$, respectively). The average water contents on 17 August for MMF9 and MMF1 were $16.87 \%$ and $13.36 \%$ in furrows, and $16.47 \%$ and $11.14 \%$ in ridges, respectively (the increments being $2.40 \%$ and $19.92 \%$, respectively). The difference of soil water content between furrow and ridge for MMF9 was gradually reduced while for MMF1 increased correspondingly. Generally speaking, after water flows into furrow un- der furrow irrigation with plastic mulch on ridge, it permeates from horizontal and vertical directions simultaneously by soil capillaries and the action of gravity during the flowing process. The permeable range and the degree of wetness at the longitudinal and transverse directions are mainly decided by the soil permeable performance and water depth in furrow or the permeating time of water in furrow (Mailhol et al., 2007). At the early growing stage, soil is loose and its porosity is relatively large, therefore, its water holding capacity is very strong. The influence of gravity for irrigation water is larger than the influence of capillary force. The amount of vertical infiltration in furrow is relatively higher. Therefore, the soil under the furrow can keep more water. In contrast, at the late growing stages (the silking stage), the soil became much more compacted and the soil porosity was also reduced gradually because of the increase of soil bulk density. Thus, vertical infiltration was limited (the clay existed in the experimental soil profile (from 60 to $100 \mathrm{~cm}$ in furrow) also reinforced this resistance) while the amount of horizontal infiltration increased. At this time, the differences of soil water contents between the furrows and ridges at the same soil layers for the treatments with larger irrigation amount reduced gradually. But as for the treatments with less irrigation amount, soil water deficit became more severe with the advance of growing stages due to serious irrigation water shortage. At the terminal growing stage, irrigation water always supplied soil water in furrows preferentially. The horizontal infiltration was difficult to anticipate when the soil in the furrows was very dry. Therefore, the soil in ridges was even drier and the differences of soil water contents between the ridges and furrows were even bigger.

The distribution of soil water content in the ridge for MMF9 showed that the soil water content reduced gradually from the surface layer to deeper layers at the early growing stage. However, the surface soil water content for MMF1 was smaller than the soil water contents below $20 \mathrm{~cm}$. This result indicated that a larger irrigation amount was better for surface soil moisture in ridge at the early growing stage because the maize with shallow roots could absorb water easily in this period. At the final growing stage, the surface soil water contents for MMF9 and MMF1 were both smaller 


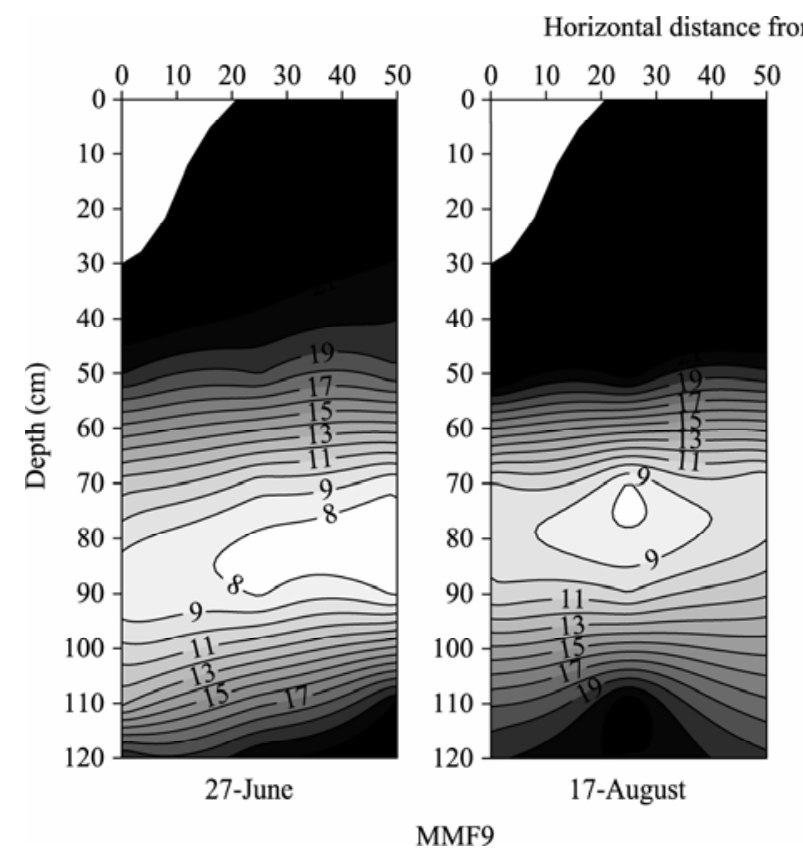

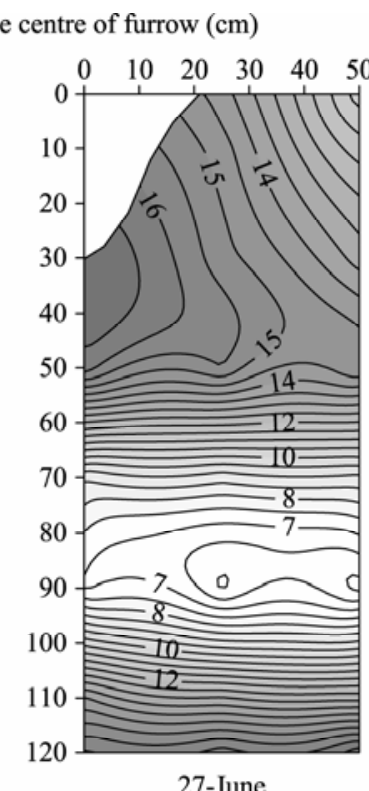

27-June

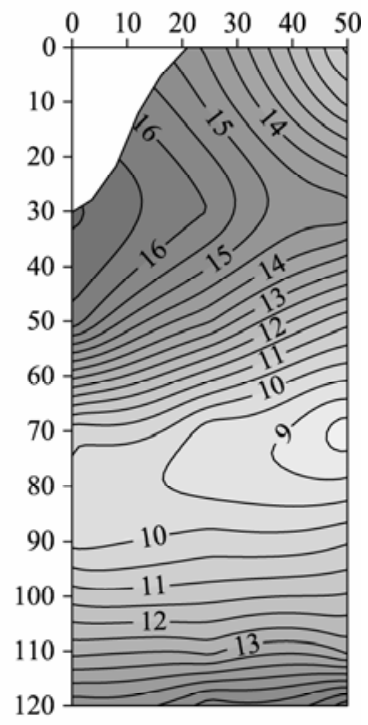

17-August

Fig. 5 Distribution of soil water content (\%) in soil profile for MMF9 and MMF1 on 27 June and 17 August

than the soil water contents below $20 \mathrm{~cm}$, without significant differences.

\subsection{Variations of soil salinity during the entire growth period}

The variations of soil salinity in furrow for different treatments before and after irrigation seasons were shown in Fig. 6. The variations of soil salinity in the layers from 0 to $40 \mathrm{~cm}$ were significant during the entire growth period. The soil salinity for each treatment was gradually increased along with the growth process. The soil salinities for different treatments basically presented a trend of MMF3 $>$ MMF6 $>$ MMF9 > MMF8 > MMF2 > MMF5 > MMF7 > MMF7 $>$ MMF4 $>$ MMF1 after each irrigation. The reduction range of soil salinity for treatments with larger irrigation amounts was smaller than that for less ones. In the secondary distribution process of water, parts of the salt entered deep into the soil together with the water flow, whereas the rest remained in the soil layer of $0-40 \mathrm{~cm}$. For the treatments with larger irrigation amounts, a plenty of salt accumulated in the surface layer during the redistribution process because large salt particles were brought into soil during the irrigation period. Below $40 \mathrm{~cm}$, the variations of soil salinity were not significant due to the influence of the clay layer.

Throughout the entire growth period, the soil salinities for the treatments with the same amount of irrigation water but different water salinity presented an increasing trend following the increase of the water salinity. For example, the average soil salinities (at depths from 0 to $100 \mathrm{~cm}$ ) for MMF7, MMF8 and MMF9 were $0.299,0.419$ and $0.514 \mathrm{dS} / \mathrm{m}$, respectively. However, the soil salinity distributions for the treatments with the same water salinity but different amount of irrigation water were relatively complex. For MMF9, MMF6 and MMF3, which had the same water salinity of $6.04 \mathrm{dS} / \mathrm{m}$, the average soil salinities (at depths from 0 to $20 \mathrm{~cm}$ ) were $0.889,0.932$ and $1.046 \mathrm{dS} / \mathrm{m}$, respectively. For soil layers from 20 to $100 \mathrm{~cm}$, the average soil salinities were $0.410,0.362$ and $0.326 \mathrm{dS} / \mathrm{m}$, respectively. That is, the more water irrigated, the more soil salt accumulated. This result indicated that for the treatments with higher water salinity, more irrigation water could easily take more salt to deep layers, which insured less salt accumulation in topsoil. For the treatments with less irrigation water, however, almost all salt brought by each irrigation process accumulated in topsoil because of limited irrigation depth, which resulted in higher soil salinity in topsoil. 


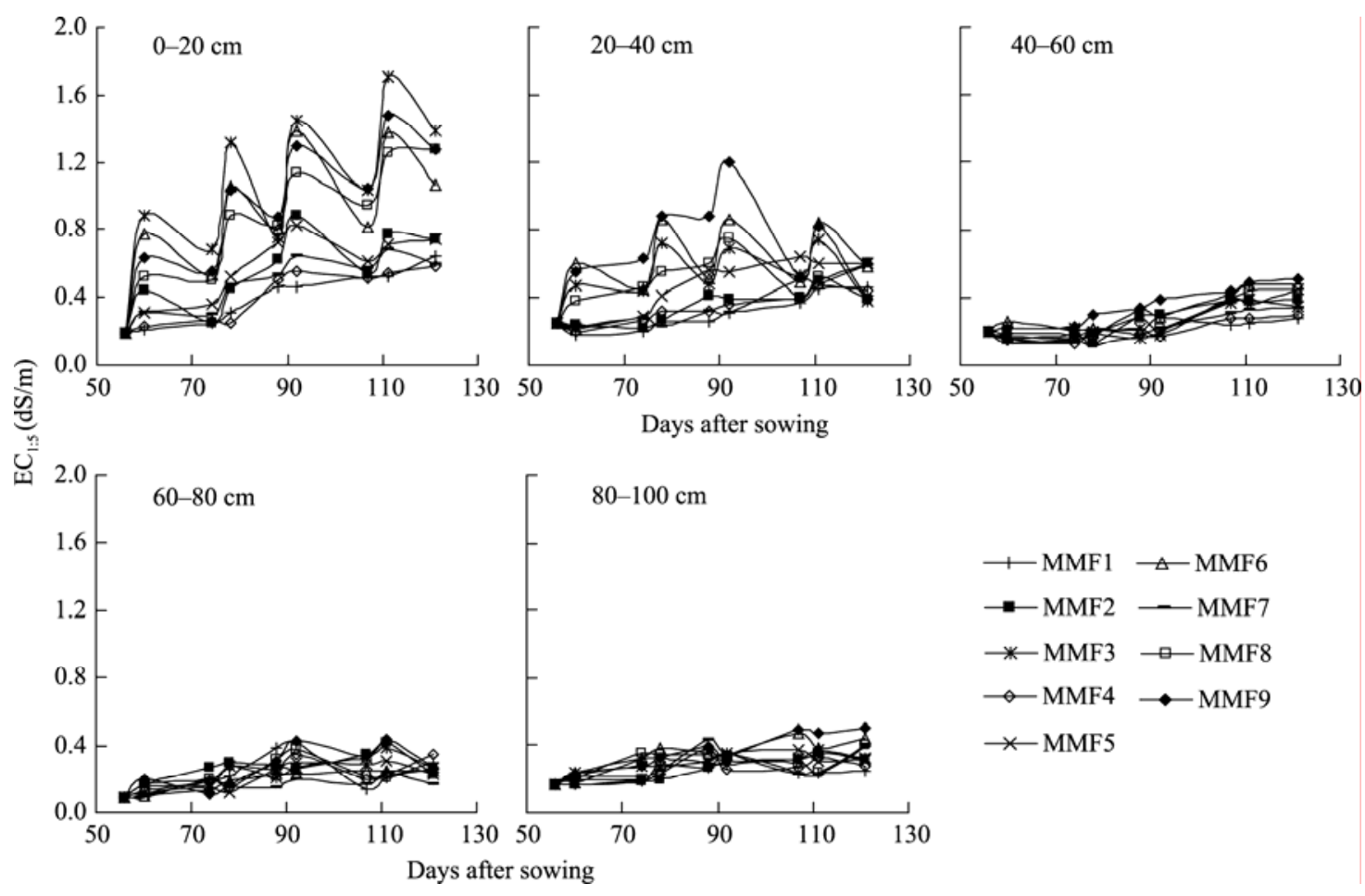

Fig. 6 The temporal dynamics of soil salinity for different treatments during the entire growth period of maize

The results for MMF7, MMF4 and MMF1, which had the same water salinity of $2.89 \mathrm{dS} / \mathrm{m}$, were quite different. During the entire growth period, the average soil salinities (at depths from 0 to $20 \mathrm{~cm}$ ) were 0.479 , 0.404 and $0.397 \mathrm{dS} / \mathrm{m}$, respectively. For soil layers from 20 to $100 \mathrm{~cm}$, the average soil salinities were $0.253,0.254$ and $0.258 \mathrm{dS} / \mathrm{m}$, respectively. That is, the more water irrigated, the less soil salt accumulated. This result indicated that for the treatments with lower water salinity, more irrigation water could bring more salt in soil. Although small parts of salt entered into deep layers with irrigation water, more salt was kept in the plough layer due to the clay that existed in the experimental soil, and moved toward the topsoil via the subsequent soil evaporation at the bottom of the furrow. For MMF7, "native" soil salt (at depths below $20 \mathrm{~cm}$ ) was leached by irrigation water. Because the water salinity for MMF7 was small, the leaching effect of irrigation water was greater than the salt accumulation effect (irrigation water brought salt to soil), thus, the soil salinity (at depths below $20 \mathrm{~cm}$ ) is relatively small.

In summary, under the condition of the same irrigation water salinity, the influences caused by different amounts of irrigation water on soil salinity are closely related to the salinity of irrigation water. Higher water salinity and less irrigation amount result in more salt accumulation in topsoil and less in deep layers. Lower water salinity and less irrigation amount result in less salt accumulation in topsoil and basically stable soil salinity in deep layers. Therefore, for the application of furrow irrigation with plastic mulch on ridge in regions where the salinity of saline water is originally higher, the amount of irrigation water should be increased properly to impel water and soil salt moving to deep layers. And for regions where the salinity is lower, the amount should be reduced for decreasing the chance of salt accumulation in topsoil.

\subsection{Spatial distribution characteristics of soil sa- linity}

Figure 7 shows the spatial distribution of soil salinity before the $2^{\text {nd }}$ irrigation (23 June) and after it (27 June) under furrow irrigation with plastic mulch on ridge. Because the ridge was mulched with plastic film during sowing, the soil salinities between the ridges and furrows were different after the sowing. The plastic film mulched on the ridge restrained evaporation of soil moisture from the ridge surface. The upward mo- 

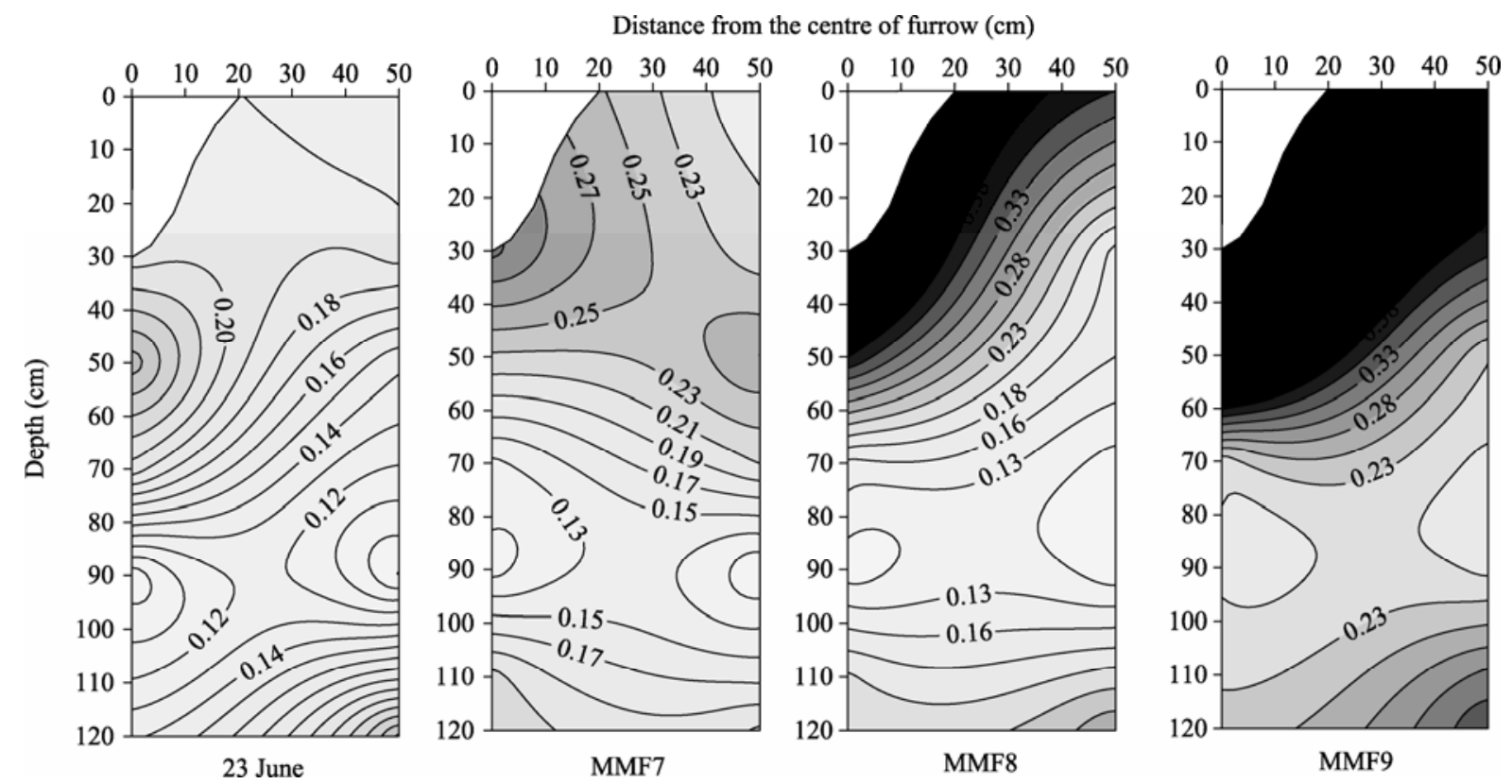

Fig. 7 Distribution of soil salinity (dS/m) in soil profile on 23 June and 27 June for MMF7, MMF8 and MMF9

vement of soil salt from deep layers was slowed down. Thus, the salt salinity in the ridge surfaces (the coordinate in Fig. 7 was $(50,0))$ was lower than that in the bottom of the furrow (the coordinate in Fig. 7 was $(0$, $30)$ ) during the same period. The soil salinity on the ridge surface before the $2^{\text {nd }}$ irrigation (23 June) was $0.181 \mathrm{dS} / \mathrm{m}$, whereas that in the furrow bottom was $0.195 \mathrm{dS} / \mathrm{m}$. Although this value was higher than the soil salinity before sowing $(0.173 \mathrm{dS} / \mathrm{m})$, the increment of soil salinity in the furrow bottom was relatively large.

The difference in soil salinity between the ridge surface and the furrow bottom was more significant after the $2^{\text {nd }}$ irrigation (27 June). The soil salinities for MMF7, MMF8 and MMF9 at the ridge surface were $0.191,0.355$ and $0.427 \mathrm{dS} / \mathrm{m}$, respectively, whereas those in furrow bottom were $0.316,0.521$ and 0.631 $\mathrm{dS} / \mathrm{m}$, respectively. For the treatment with the same amount of irrigation water, salt accumulation in the ridge surface was much smaller than that in the furrow bottom. This rule is quite different from the spatial distribution of soil salinity for traditional furrow irrigation. The reasons for this phenomenon mainly include three aspects as follows.

Firstly, the means for water infiltration in furrows and ridges are different and water infiltration quantities are also different under furrow irrigation. Water infiltration in the furrow is mainly subject to vertical infiltration, whereas water infiltration in the ridge is mainly subject to horizontal lateral infiltration. Comparatively speaking, the speed of salts entering in the furrow is faster than entering in the ridge. Much salt can be accumulated in a short time. Lateral infiltration of water is relatively slow. Parts of the salt is deposited by chemical reaction with the soil minerals (adsorption and desorption) in this process and parts is probably blocked by soil filtering. Therefore, the amount of salt which would originally enter into the ridge is reduced. Thus, the amount of soil salt accumulated in the furrow is greater than that in the ridge because water permeated in the furrow during each irrigation period.

Secondly, soil water and salt distribution and transportation under traditional furrow irrigation are very different from those under furrow irrigation in combination with plastic film. Generally, in arid regions with rare precipitation, the loss of salt in furrow is mainly caused by irrigation leaching and the salt accumulation mainly comes from the salt brought by irrigation and salt moved upwards by soil evaporation. Salt accumulation in ridge mainly comes from the salt brought by irrigation and salt movement evoked by soil evaporation and plant transpiration whereas the loss of salt is mainly caused by the uptake of crops. 
The amount of salt loss in the ridge is far less than the salt supply and the salt accumulation is also higher than that in the furrow because of the lack of direct leaching. For the ridge under furrow irrigation with plastic mulch on ridge, however, the channels from which soil water evaporates to the air is blocked because mulching film covers a layer of airtight physical barrier on the soil surface. Water recycle can be merely implemented under the film. Under this specific condition, moisture condenses as water droplets consistently under the film surface and then drops in soil. Although the air under the film cannot be saturated, high humidity is maintained to resist excessive soil salt accumulation in the surface layer caused by soil evaporation. However, for the irrigation furrow, salt accumulation in the soil surface appears because of the reduction of the mulching film area and the effects of soil evaporation.

Thirdly, soil texture affects soil water and salt transportation. In this experimental field, there is clay subsoil layer within $60-100 \mathrm{~cm}$. Thus, salt can be held in the surface of clay layer because of the low permeability of the subsoil. Consequently, more salt is kept in shallow soil.

Soil salinity in $70-100 \mathrm{~cm}$ was universally low because of the clay interlayer, which formed an apparent salt barrier zone. Due to this reason, salt salinity at the depths below $100 \mathrm{~cm}$ for the ridge and furrow had no significant differences. However, parts of the salt still reached deep soil by crossing the clay layer, according to the comparison with the soil salinity on 23 June. Average salt salinities at the depths below $100 \mathrm{~cm}$ for MMF7, MMF8 and MMF9 were $0.199,0.235$ and $0.296 \mathrm{dS} / \mathrm{m}$, respectively, which were higher by $17.75 \%, 39.05 \%$ and $75.15 \%$ than the soil salinity before sowing $(0.169 \mathrm{dS} / \mathrm{m})$.

In summary, furrow irrigation with plastic mulch on ridge has the characteristics of lower soil salinity in the ridge than in the furrow. Therefore, the proposed method is good for crop planting on the ridges.

\subsection{Correlation analysis of irrigation water salin- ity, irrigation amount and soil salinity}

The correlation of irrigation amount and soil salinity in various soil layers was shown in Fig. 8. The average soil salinity in each soil layer was different with the change of irrigation amount. The surface layer
$(0-20 \mathrm{~cm})$ is an irrigation-influenced layer and the soil salinity decreased at first, and then increased with the increase of irrigation amount. That was to say, moderate amount of irrigation water was favorable for leaching salt while large amount tended to accumulate salt. The average soil salinity in $20-40 \mathrm{~cm}$ increased with the irrigation amount, and was in a logarithm raising trend. The equation for correlation curves was $y=0.2679 \ln (x)-1.6859 \quad\left(\mathrm{R}^{2}=0.9913\right)$. Soil salinity in deep layers changed slightly with the change of water amount.

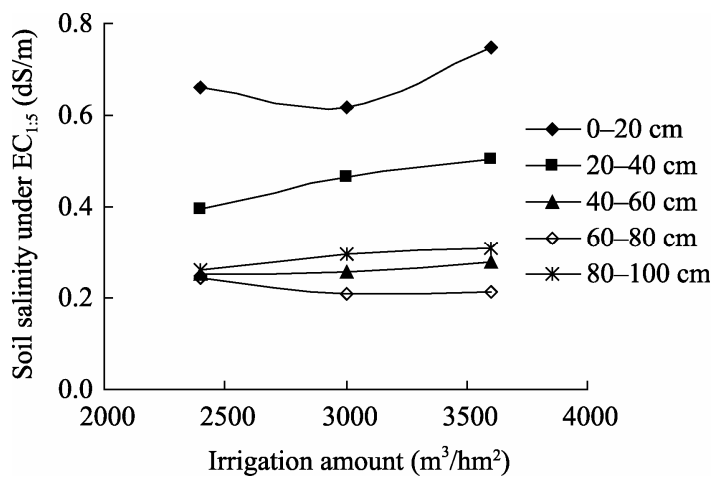

Fig. 8 Relationship between irrigation amount and soil salinity

Figure 9 shows the correlation of irrigation water salinity and soil salinity in various soil layers. Soil salinity in each soil layer all increased with the irrigation water salinity. The equation for correlation curves for the surface layer $(0-20 \mathrm{~cm})$ was: $y=0.0133 x^{2}+$ $0.0212 x+0.2664\left(\mathrm{R}^{2}=1\right)$ and for the $20-40 \mathrm{~cm}$ layer was: $y=0.0102 x^{2}-0.0202 x+0.3104\left(\mathrm{R}^{2}=1\right)$. This result indicated that the salinity of irrigation water was still the main factor influencing soil salinity in furrow irrigation with plastic mulch on ridge.

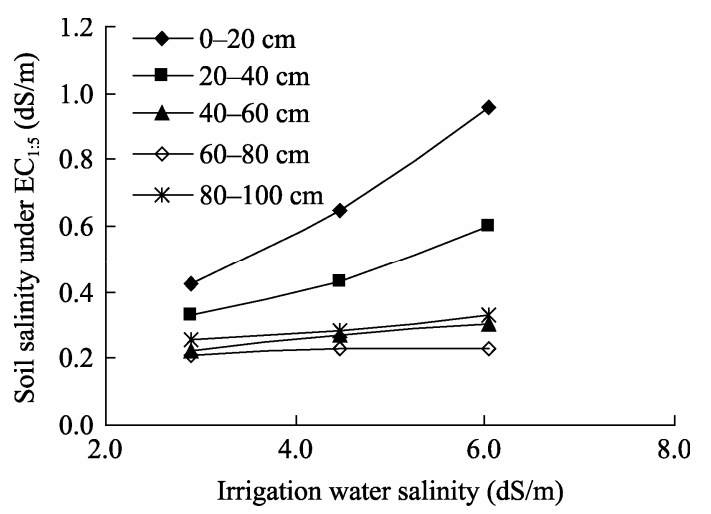

Fig. 9 Relationship between irrigation water salinity and soil salinity 


\section{Conclusions}

Based on the field experiment conducted in 2010, the paper studied the dynamics of soil water-salt transportation and its spatial distribution characteristics under furrow irrigation of saline water with plastic mulch on ridge. The results showed that although irrigation with water of high salinity could effectively increase soil water content, the irrigation amount was still the major decisive factor affecting the soil water content in saline water irrigation. During the early growth stage, MMF1 had the highest difference of soil water content between furrows and ridges (the water content in furrow was higher by $13.70 \%$ than in ridge). During the terminal growth stage, the difference of soil water content between furrows and ridges for MMF9 was gradually reduced while for MMF1 increased correspondingly.

The soil salinities increased with the water salinity for the treatments with the same amount of irrigation water but different water salinity. But for the treatments with the same water salinity but different amounts of irrigation water, when water salinity was 6.04 $\mathrm{g} / \mathrm{L}$, less water resulted in high soil salinity in topsoil; when water salinity was $2.76 \mathrm{~g} / \mathrm{L}$, less water resulted in low soil salinity in topsoil. The salinity of irrigation water was still the main factor influencing soil salinity in furrow irrigation with plastic mulch on ridge.

\section{Acknowledgements}

This research was supported by the National Natural Science Foundation of China $(91025002,30970492)$ and the National Key Technology R \& D Program (2012BAC08B05).

\section{References}

Ben-Asher J, Tsuyuki I, Bravdo B A, et al. 2006. Irrigation of grapevines with saline water: I. leaf area index, stomatal conductance, transpiration and photosynthesis. Agricultural Water Management, 83 (1-2):13-21.

Crevoisier D, Popova Z, Mailhol J C, et al. 2008. Assessment and simulation of water and nitrogen transfer under furrow irrigation.
Agricultural Water Management, 95(4): 354-366.

Evans R G, Smith G J, Oster J D, et al. 1990. Saline water application effects on furrow infiltration of red-brown earths. Transactions of the ASAE, 33(5): 1563-1572.

Feng D, Zhang J P, Cao C Y, et al. 2011. Soil water and salt migration under border irrigation with saline water. Journal of Soil and Water Conservation, 25(5): 48-52.

Forrest T, Terence H P, Harold R D. 1985. Infiltration under Surge Irrigation. Transactions of the ASAE, 28(2): 517-521.

Guo T L, Chi D C, Wang Q J, et al. 2005. Experimental study on salt and water movement affected by mineralization degree of infiltration water. Transactions of the Chinese Society of Agricultural Engineering, 21(Suppl.): 84-87.

Jiang J, Feng S, Huo Z, et al. 2010. Effect of irrigation with saline water on soil water-salt dynamics and maize yield in arid Northwest China. Wuhan University Journal of Natural Sciences, 15(1): 85-92.

Mailhol J C, Crevoisier D, Triki K. 2007. Impact of water application conditions on nitrogen leaching under furrow irrigation: Experimental and modeling approaches. Agricultural Water Management, 87(3): 275-284.

Mantell A, Frenkel H, Meiri A. 1985. Drip irrigation of cotton with saline-sodic water. Irrigation Science, 6: 95-106.

Ministry of Agriculture. 2000. 948 Project: Acceptance Technology Report for Technique of Brackish Water for Farmland Irrigation (NO. 961048). Beijing: Soil Research Institute of Chinese Academy of Agricultural Sciences, 55.

Moreno F, Cabera F, Andreu L, et al. 1995. Water-movement and salt leaching in drained and irrigated marsh soils of Southwest Spain. Agricultural Water Management, 27(1): 25-44.

Oster J D. 1994. Irrigation with poor quality water. Agricultural Water Management, 25(3): 271-297.

Rengasamy P. 2002. Transient salinity and subsoil constraints to dryland farming in Australian sodic soil: an overview. Australian Journal of Experimental Agriculture, 42: 351-361.

Rhoades J D, Chanduvi F, Lesch S. 1999. Soil salinity assessment methods and interpretation of electrical conductivity measurements. FAO Irrigation and Drainage Paper, 57: 84-91.

Tiercelin J R, Vidal A. 2006. Treaty of Irrigation, $2^{\text {nd }}$ ed. Paris: Lavoisier.

Yang X Y, Du T S, Pan Y H, et al. 2003. Scheduling irrigation for maize under different irrigation methods in Minqin Oasis. Journal of Irrigation and Drainage, 22(3): 22-24.

Zohrab A S, Wynn R W, Lyman S W. 1985. Infiltration under surge flow irrigation. Transactions of the American Society of Agricultural Engineering, 28(5): 1539-1542. 